\title{
The Comparative Academic Performance of International Students
}

\begin{abstract}
Alan Olsen, Zena Burgess, and Raj Sharma
Alan Olsen is director of Strategy Policy and Research in Education Limited, $3 \mathrm{H}$ Old Peak Mansion, 5 Old Peak Road, Hong Kong. E-mail: Alan.Olsen@spre.com.hk. Zena Burgess was director of international operations at Swinburne University of Technology, Melbourne, Australia. Raj Sharma is associate director and senior research fellow at Swinburne University of Technology, Melbourne, Australia.
\end{abstract}

Tternational students do just as well as Australian students. 1 This is the key finding from a study of the academic performance of 338,000 full-time students at 22 Australian universities in 2003.

The results of the study are important to international education professionals globally at a time when there have been allegations that Australian universities were dropping standards to favor foreign students. The Sydney Morning Herald claimed in June 2005 to have found evidence of quality falling at universities to cater to international students with poor English seeking degrees so as to be accepted for migration.

The research proved these allegations to be untrue. Australian students passed 89.4 percent of courses attempted, international students 88.8 percent. The results suggest that in their recruitment of international students Australian universities set their standards at about the right level.

Consistent with research globally, the study found a gender difference. Female students passed 9I.6 percent of courses attempted, male students 86.5 percent. Simply, girls did better than boys.

\section{The Study}

Australia uses the "student progress rate" as the indicator of the extent to which students complete their studies with maximum efficiency. The student progress rate for a student, between $\circ$ percent and Ioo percent, is the proportion of study load passed to study load attempted or, simply, courses passed as a percentage of courses attempted. The student progress rate is a key performance indicator in the Australian university system, with all universities maintaining the rates for all students.

In 2004, the 38-member universities of the Australian Vice-Chancellors' Committee, the council of Australia's university presidents, were asked to participate in a study using student progress rates for 2003; 22 universities took part.

For both Australian and international students, the study included only students studying full time on campus in Australia. There was no international student population with which to compare Australian students studying part time, and there was no Australian student population with which to com- pare international students studying at offshore campuses.

The 22 participating universities provided student progress rates for 2003 on 338,445 full-time students on campus in Australia: 264,516 ( 78 percent) Australian students and 73,929 (22 percent) international students; I84,002 (54 percent) females and 154,443 ( 46 percent) males.

The research compared student progress rates for Australian students and international students. The 264,516 Australian students passed 89.4 percent of what they attempted, the 73,929 international students 88.8 percent. Overall, there was no difference.

\section{INSTITUTIONS}

Australian students outperformed international students at I3 universities, international students outperformed Australian students at 5 universities, and at 4 universities there was no difference.

\section{Field of Education}

Australia conforms to an international classification on broad field of education. Student progress rates vary across these fields, ranging from 82.9 percent for students in information technology to 94.5 percent for students in health sciences.

The research compared student progress rates for Australian and international students in each broad field of education. In architecture/building, health, and business, Australian students outperformed international students. In science, information technology, engineering, education, arts, and agriculture/environment, international students outperformed Australian students; and in creative arts there was no difference.

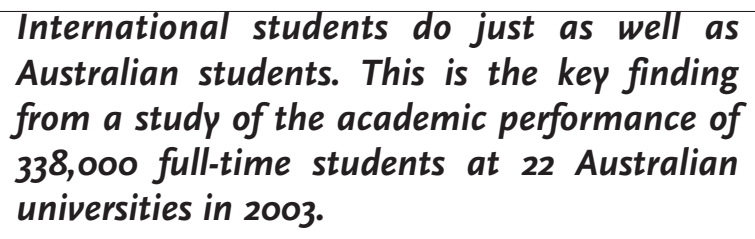
Australian students. This is the key finding from a study of the academic performance of 338,000 full-time students at 22 Australian universities in 2003.

\section{GENDER}

The 148,963 Australian female students passed 9I.7 percent of courses attempted, the II5,553 Australian males 86.4 percent. The 35,039 international female students passed 90.9 percent of courses attempted, the 38,890 international males 86.8 percent. Overall, the 184,002 female students passed 9ı.6 percent of courses attempted, the 154,443 males 86.5 percent. Simply, girls did better than boys.

The gender makeup of the Australian and international cohorts differs: 56 percent of Australian students are female, and 47 percent of international students are female. The Australian cohort, relatively heavy with females, might be expected to outperform the international cohort. But the research found no difference overall. 
The 148,963 Australian female students passed 91.7 percent of courses attempted, the 35,039 international females 90.9 percent. The II5,553 Australian male students passed 86.4 percent of courses attempted, the 38,890 international males 86.8 percent. Overall, there was no difference: the 264,516 Australian students passed 89.4 percent of courses attempted, the 73,929 international students 88.8 percent.

\section{Levels of Study}

There were I,908 postgraduate research students in the study. Progress rates for postgraduate research students need to be treated with caution, so these I,908 postgraduate research students, 0.6 percent of the study, were removed from this analysis by level of study.

The 16,839 Australian postgraduate coursework (i.e., not postgraduate research) students passed 94.7 percent of courses attempted, the 246,127 Australian undergraduates 89.3 percent. The 22,592 international postgraduate coursework students passed 92.9 percent of courses attempted, the 50,979 international undergraduates 87 percent. Overall, the 39,43I postgraduate coursework students passed 93.7 percent of courses attempted, the 297,I06 undergraduates 88.9 percent. Simply, postgraduates did better than undergraduates.

The makeup by level of study of the Australian and international cohorts differs: 6 percent of Australian students are postgraduate coursework students, 3I percent of international students are postgraduate coursework students. The international cohort, relatively heavy with postgraduate coursework students, might be expected to outperform the Australian cohort. It is perhaps because of the makeup by levels of study that the research found no difference overall.

\section{The key finding from this study is that at the 22 universities in 2003 international students per- formed as well as Australian students.}

The 246,I27 Australian undergraduates passed 89.3 percent of courses attempted, the 50,979 international undergraduates 87 percent. The I6,839 Australian postgraduate coursework students passed 94.7 percent of courses attempted, the 22,592 international postgraduate coursework students 92.9 percent. Overall, there was no difference: the 262,966 Australian students passed 89.6 percent of courses attempted, the 73,57I international students 88.8 percent.

\section{CONCLUSION}

The key finding from this study is that at the 22 universities in 2003 international students performed as well as Australian students. Two other results are very clear. Female students performed better than male students, and postgraduate coursework students performed better than undergraduate students.

The Australian cohort, relatively heavy with females, might be expected to outperform the international cohort, but the international cohort, relatively heavy with coursework postgraduate students, might be expected to outperform the Australian cohort. Overall, there is no difference: Australian students passed 89.4 percent of courses attempted, international students passed 88.8 percent.

A report of this study, rich in tables and charts, can be downloaded from the International Education Association of Australia website: www.ieaa.org.au/news/.

\section{Pushing Through Bologna Reforms: The Hungarian Case}

\section{Anthony MORGan}

Anthony Morgan is professor of higher education in the Department of Educational Policy and Leadership at the University of Utah. E-mail: anthony.morgan@ed.utah.edu.

Hungary signed off on the Bologna process in 1999 and 1 was admitted to the European Union in May 2004. The Hungarian Parliament passed a new higher education law in June 2005-driven in large measure by the pressures and provisions of the Bologna process. This relatively rapid adoption of change has hit a snag, however, as certain provisions of the new law have been challenged in Hungary's Constitutional Court, which began hearings on the matter this fall. In the meantime, governmental decrees have filled the gap between law and required policies for implementation. Any required revisions in the challenged law will have to be renegotiated through Parliament by a government facing reelection in spring 2006.

This article was based on a series of interviews in August and September 2005 conducted at the Ministry of Education and the University of Szeged as well as on a review of documents in English that have been part of the Bologna process.

\section{Degree Structural Changes}

Hungary has opted to move from its current five-year diploma to a three-year baccalaureate, a two-year master's degree, and the PhD as the highest degree. Government officials see this structure as not only complying with the accords of the Bologna process but also reducing the amount of government subsidies for state-supported students. By contrast, many faculty see a three-year first degree as a threat to the quality of pro- 